\title{
PRELIMINARY LIST OF PLANTS FOUND IN THE KALAHARI GEMSBOK NATIONAL PARK
}

\author{
by O. A. LEISTNER
}

Botanical Station, Kimberley (Division of Botany)

Published with permission of the Secretary for Agriculture.

This list was compiled from collections of Dr. R. Story (May, 1956) and Messrs. A. M. Brynard (June, 1953; February, 1955) and O. A. Leistner (December, 1957; June, 1958). The notes are mainly based on my own observations.

The Kalahari Gemsbok National Park is roughly triangular in shape and covers an area of about 4,000 square miles. It forms the northern extension of the district Gordonia which is wedged in between South West Africa and the Bechuanaland Protectorate. The dry river courses of the Nossob and the Auob traverse the Park and join near its southern boundary.

Except in the vicinity of the rivers and a number of pans the whole area is covered by a thick layer of red sand thrown into dunes. Outcrops of calcrete and silicrete are found on river banks and around pans. The beds of the rivers consist of whitish silty sand with a high lime content.

The Kalahari Gemsbok National Park and the adjoining Bechuanaland Game Reserve have been tentatively divided into six zones as shown on the accompanying map (Leistner 1959). In the northernmost zone the flora is richest and the mean annual rainfall highest (probably about $250 \mathrm{~mm}$ ), and in zone $\mathrm{VI}$ the flora is poorest and the rainfall lowest (probably $140 \mathrm{~mm}$ and less). Plants confined to zone I, which falls entirely outside the area of the Kalahari Gemsbok National Park, have not been listed.

The flora of the Park is poor owing to low rainfall and uniform conditions. Nevertheless it is highly interesting as it is made up of at least four different floral elements:

1. A tropical to sub-tropical Kalahari element represented by e.g. Terminalia sericea, Rhus commiphoroides, Aristida meridionalis and Aristida graciliflora. This element is found in a typical form in zone I. Within the boundaries of the Kalahari Gemsbok National Park it is more or less restricted to zone II. 
2. An arid Namaqua-Namib element represented by Parkinsonia africana, Crotalaria spartioides, Asthenatherum glaucum and Brachiaria glomerata. It is mainly found in the southern parts of the Park, especially in zone VI. To the north, species referable to it become rarer in each consecutive zone. No plants regarded as belonging to this element were collected by the Vernay-Lang Kalahari Expedition (Bremekamp \& Obermeyer, 1935) which traversed the central and northern regions of Bechuanaland.

3. An arid Karoo element confined to compact calcareous soils especially on river banks and around pans. Species belonging here are Rhigozum trichotomum, Eriocephalus pubescens, Pentzia incana and Aristida obtusa.

4. A river-bed flora composed of widespread species that are often of a weedy nature like Asclepias fruitcosa, Blumea gariepina, Chloris virgata and Tragus racemosus.

The Tenebrionid fauna of this region shows distribution patterns that are remarkably similar to that of the flora (Koch, unpubl.).

It is estimated that the list includes about $75 \%$ of the species that occur in the Park. As would be expected the number of geophytes, hemicryptophytes and ephemerals found in this area is large. Most of the plants that have not yet been recorded are expected to fall into these groups.

About ten species have not been listed although they were seen in the Kalahari Gemsbok National Park. These were in too poor a condition to collect or to identify with certainty. Three important species which were identified with certainty are given in the list although they were not collected.

Only common names in general use among the inhabitants of the area are indicated. The collector's number given with each species is in most cases the first scientific record of that plant from the Park.

The families and genera are arranged according to Phillips (1951), and the species in alphabetical order.

\section{FUNGI}

Broomeia ellipsospora v. Höhnel

Loose red sand; rare. A. van der Westhuizen, KMG 8175.

Gyrophragmium delilei Mont.

On silt in river-bed. Story 5510.

Schizostoma laceratum Ehrenb. ex Lev.

Under Acacia giraffae on white sand on bank of Auob. This rare fungus has only been collected twice before in the Union in the vicinity of Williston. Leistner 1135. 
Terfezia pfeilii P. Henn.

According to Dinter (1912) and a Game Ranger of the Kalahari Gemsbok National Park two different species of truffles occur on dunes in the Kalahari. At present, however, only $T$. pfeilii has been identified from the Park. Story 5616 was growing near Aristida ciliata and Dinter mentions that truffles are usually found near Aristida species with plumose awns. Story 5616.

\section{PTERIDOPHYTA}

Marsilea sp. cf. M. macrocarpa Presl.

Moist depression in bed of Nossob in zone II; locally abundant. Leistner 1018.

Marsilea sp.

Depression between dunes. Story 5589.

\section{GRAMINEAE}

Tragus berteronianus Schult.

Rare weedy annual confined to river-beds. Leistner 1020.

Tragus racemosus (L.) All. (Klitsgras).

Similar to Tragus berteronianus in habit and distribution but much more common. Leistner 1021.

Diplachne fusca (L.) All.

Tufted perennial apparently confined to depressions in bed of Nossob. Leistner 1017.

Triraphis fleckii Hack.

Annual favouring rather compact calcareous sand as it is found on river banks, in depressions and around pans. Story 5487.

Eragrostis annulata Rendle

Tufted annual on white sand in river-beds. Story 5491.

Eragrostis atherstonei Stapf

Erect perennial noticed in river-beds and on crests of dunes. The form growing in rivers is rare and less typical than that found commonly on dunes. Story 5597.

\section{Eragrostis bicolor Nees}

Low, densely tufted perennial in bed of Nossob in zones II and III. Abundant in parts. Valuable grazing. Story 5507.

Eragrostis brizantha Nees

Annual found mainly in sandveld in vicinity of river banks. Story 5538. 


\section{Eragrostis lehmanniana Nees}

The commonest grass in the Park. Besides the typical form (Story 5548) a slightly different one is found in this area (Leistner 1011). It has spikelets that look exactly like those of Eragrostis bicolor: the lemmas are variegated and are purplish below with a yellow tip. E. lehmanniana is mainly found in the sandveld but is also present in the river-beds.

It has not yet been established whether the different forms have a distinct distribution as they cannot be distinguished in a dry state. Well grazed when green.

\section{Eragrostis porosa Nees}

Common annual on calcareous sand in beds and on banks of rivers. Story 5509.

Eragrostis rotifer Rendle

Tall perennial locally common in depressions in river-beds. Story 5497. Eragrostis truncata Trin.

Rhizomatous perennial forming dense tufts; locally abundant on pans and in side arms of Nossob in zones II and III. Story 5520.

Chloris virgata Sw. (Vleigras).

Annual or weak perennial; abundant in patches in river-beds; rare in marginal zone of pans. Story 5586 .

Fingerhuthia africana Lehm. (Kalkgras).

Densely tufted perennial confined to calcrete outcrops on river banks. Brynard 220.

Sporobolus ioclados Nees var. usitatus (Stent) Chip.

Stoloniferous perennial seen only on calcrete outcrops on river banks. Story 5501.

\section{Sporobolus rangei Pilger}

Robust stoloniferous perennial confined to marginal zone of pans; often grazed down. Story 5582.

Schmidtia kalahariensis Stent (Suurgras).

The commonest annual grass in the Park, often abundant on loose white to pink sand. Sometimes an indicator of overgrazing. Grazed in all stages but mainly when young. Areas covered by dead culms that have fallen over are locally known as bloudak. Story 5500 . 
Enneapogon brachystachyus (Jaub. et Spach) Stapf

River-beds, river banks, marginal zones of pans and pan surfaces. Annual, but often regarded as perennial as new shoots develop from old tufts within a few days after rain (hence its name agtdaegras). The development of new growth is due to the germination of seeds borne in spikelets hidden in the basal leaf-sheaths. Good grazing, especially favoured by springbok. Story 5518.

\section{Asthenatherum glaucum (Nees) Nevski (Ghagras).}

Only found on deep red sand. Effective sand binder and valuable from a grazing point of view. Although it appears to be hard, the basal internodes retain some moisture even during the dry season. Sometimes referred to as Danthonia glauca Nees. Story 5545.

Aristida amabilis Schweickerdt (Steekriet).

Confined to crests of dunes where it is common to abundant. Forms numerous rhizomes that can be several metres long. The only perennial grass that is adapted to conditions on very loose dunes. Young shoots are cropped by game. Until recently this species was confused with Aristida namaquensis (Nees) Trin. et Rupr. which it resembles very closely. It is doubtful whether $A$. namaquensis occurs in the Park. Story 5565.

Aristida ciliata Desf. var. tricholaena Hack. (Langbeenboesmangras).

On light calcareous sand: river banks, marginal zones of pans and depressions in sandveld. Never common. Sometimes growing in association with Aristida obtusa which generally prefers harder soils. Well grazed. Story 5513.

Aristida curvata (Nees) Trin. et Rupr. (Steekgras).

Weedy perennial found only in river-beds and on river banks. Eaten in young state. Brynard 394.

Aristida curvata (Nees) Trin et Rupr. (Steekgras).

Weedy annual with a distribution similar to that of Aristida congesta Roem. et Schult. Story 5508.

Aristida graciliflora Pilger

Glaucous perennial recorded only from the sandveld in zones I and II. Leistner 1136.

Aristida meridionalis Henr. (Staaldraad).

Tall, hard perennial found in the sandveld of all zones except VI. Rarely grazed. Story 5599. 
Aristida obtusa Del. (Kortbeenboesmangras).

Confined to hard calcareous sandy soil in river-beds, on river banks, around and on pans and in depressions in the sandveld. Large areas on the banks of the Nossob in zone II are dominated by this valuable grass which is probably grazed by all antelopes in the Park. Story 5512.

Aristida uniplumis Licht. (Blinkhaargras).

One of the most common perennials in sandveld. Valuable grazing grass retaining some nutritive value even during winter. Story 5489.

Panicum coloratum L. (Buffelgras).

Confined to river-beds where it is the commonest perennial grass. It is often locally abundant and very important from a grazing point of view. Story 5496.

Setaria verticillata (L.) Beauv. (Klitsgras).

A weedy annual found mostly under trees in river-beds, on river banks and in sandveld. Story 5575.

Brachiaria glomerata (Hack.) A. Camus (Soetgras).

Annual confined to loose red sand. Favoured by game. Story 5486 .

Brachiaria marlothii (Hack.) Stent

Rather rare annual found in depressions in river-beds. Leistner 1156.

Cenchrus ciliaris L.

Tufted perennial seen only in depressions in bed of Nossob. Valuable pasture gras but unimportant due to its scarcity. Leistner 1163.

Dichantium papillosum (Hochst.) Stapf.

Confined to depressions of river-bed in zone II. Leistner 1015.

\section{CYPERACEAE}

Fimbristylis exilis Roem. et Schult.

Annual widely distributed in sandveld. Leistner 1148.

\section{LILIACEAE}

Eriospermum sp. cf. E. corymbosum, Bak.

On calcareous sand in depressions in sandveld. Locally frequent. Leistner 1008.

Albuca sp. ? Story 5596.

Scilla sp. cf. S. nelsonii Bak.

Recorded only from one locality in sandveld. Leistner 1001. 
Pseudogaltonia clavata (Bak.) Phill.

Locally common in bed of Auob. Story 5524.

Asparagus bechuanicus Bak. (Katdoring).

Rare perennial in marginal zone of pans and in depressions in sandveld. Leistner 1009.

Asparagus sp. cf. A. plumosus Bak.

Scandent shrub found in river-beds, on river banks and in sandveld. Leistner 1162.

Boöphone disticha (L.f.) Herb.

\section{AMARYLLIDACEAE}

Probably widely distributed in sandveld. Poisonous. Leistner 1042.

Nerine duparquetiana Bak.

Recorded from river banks along Auob and pan margins. It is doubtful whether this species is distinct from Nerine laticoma (Ker.) Dur. et Schinz. Story 5592.

\section{LORANTHACEAE}

Loranthus oleaefolius Cham. et Schlechtd.

Parasitic on Acacia spp. Only seen in zone II where it is rare. Story 5553.

\section{POLYGONACEAE}

Oxygonum alatum Burch. (Suring).

A common summer annual found in the sandveld of all zones. Favoured by game. Brynard 415 .

Oxygonum? dregeanum Meisn.

Difficult to distinguish from $O$. alatum and probably similar in distribution. Story 5551.

Chenopodium album $\mathrm{L}$.

\section{CHENOPODIACEAE}

Weedy annual usually growing under trees in beds and on banks of rivers and in sandveld. Story 5564.

Salsola rabieana Verdoorn (Groot ganna).

Confined to pans, marginal zone of pans and side arms of Nossob in zones I and II. Valuable food plant, Leistner 1022. 
Salsola sp. (Codd 5889).

Story 5533.

Lophiocarpus burchellii Hook. f.

On calcareous sandy soil on river banks and around pans. Mainly found in southern parts of Park. Brynard 410.

\section{AMARANTACEAE}

Celosia linearis (Schinz) Schinz

A frequent annual in sandveld. The form occurring in this area is sometimes called Celosia fleckii. Story 5573.

Hermbstaedtia odorata (Burch.) T. Cooke

Rather similar in aspect to Celosia linearis but perennial and styles of old flowers not exserted. Occasional in sandveld. Brynard 414.

Amarantus angustifolius Lam.

Occasional weedy annual in bed of Nossob. Leistner 1066.

Amarantus thunbergii Moq.

Weedy annual in river-beds and on red sand. In sandveld it was only noticed under trees. Story 5614.

\section{NYCTAGINACEAE}

Boerhaavia sp. cf. B. diffusa L.

Rare prostrate perennial seen only in bed of Nososb. Leistner 1048.

\section{PHYTOLACCACEAE}

Limeum arenicolum Schellenb.

Annual commonly found in summer on loose red sand. Occurs mainly in southern parts of Park. Twice seen to be eaten by springbok. Leistner 1030.

Limeum argute-carinatum Wawra et Peyr. var. kwebense (N.E.Br.) Friedr.

On calcareous sandy soil on river banks. An unidentified species of Limeum that is widely distributed in the sandveld may also belong here. Story 5580 .

Semonvillea fenestrata Fenzl

Annual found occasionally in sandveld. Leistner 1003. 
Gisekia miltus Fenzl

Annual widely distributed in sandveld. Brynard 387.

\section{AIZOACEAE}

Plinthus crytocarpus Fenzl (Ganna).

River banks. Story 5490.

Plinthus karooicus Verdoorn (Ganna).

Calcareous sand on river banks. Story 5514.

Plinthus laxifolius Verdoorn (Ganna).

This perennial is apparently confined to the sandveld in zones V and VI. Said to be good fodder plant. Story 5558.

Plinthus sericeus Pax (Sandganna).

Widespread, extremely variable bush occurring on calcareous soil as well as on red sand. Food plant of some importance. Story 5530.

Galenia africana L. (Kraalbos).

This shrub which prefers rather compact sandy soils with a high lime content was seen only in the bed of the Nossob in zones III and IV and on a pan-like depression in VI. Story 5494.

Aizoon fruticosum Schellenb.

Hard calcareous soil on bank of Nossob. Story 5525.

Tetragonia arbuscula Fenzl

Seen in sandveld of zone II and on a red dune along the Avob in III. This shrub which is regarded as one of the most valuable fodder plants in the Karoo Region was untouched by game even where it was growing in a well grazed area near a windmill. Leistner 1014.

\section{CARYOPHYLLACEAE}

Pollichia campestris Ait.

Low perennial with woody base occurring in river-beds, on river banks and in sandveld. It was only seen under trees, which can possibly be explained by its distribution by birds - its fruit are palatable berries - and its dependence on shady localities. Story 5570. 
Cleome suffruticosa Schinz

\section{CAPPARIDACEAE}

Tall annual growing in sandveld. Brynard 463.

Cleome sulfurea Bremek. et Oberm.

Annual in sandveld. Mainly in northern areas. Story 5585.

Gynandropsis pentaphylla (L.) DC. (Wilde-ertjie).

Annual seen in sandveld and around pans. Brynard 411 .

Boscia albitrunca (Burch.) Gilg. et Ben. (Witgat).

Common tree in sandveld but also found on calcrete outcrops along rivers. Probably due to browsing and the action of wind and sand it often develops into a low hemispherical shrub. One of the most important food plants in the Park as it retains green, juicy leaves throughout the year. Offers shelter to many forms of animal life as well as to certain plants. Story 5523.

Coronopus integrifolius Spreng.

\section{CRUCIFERAE}

Annual growing on river banks and around pans. Brynard 398 .

Oligomeris capensis Thunb.

\section{RESEDACEAE}

Shrublet apparently confined to marginal zone of pans in zone VI. Leistner 990.

Vahlia capensis Thunb.

\section{SAXIFRAGACEAE}

Low perennial growing around pans. Story 5591.

\section{ROSACEAE}

Neuradopsis bechuanensis Bremek. et Oberm.

Tomentose annual confined to sandveld; rare. Brynard 461.

Grielum obtusifolium E. Mey.

Low annual found mainly on river banks. Seems to prefer red sand overlying calcrete. Sometimes locally common. Story 5615 .

\section{LEGUMINOSAE}

Albizia anthelmintica (A. Rich.) A. Brogn. (Bonthout).

Tree confined to the sandveld of zones I and II. In I it is locally frequent while in II it is rare. Leistner 1045. 
Acacia detinens Burch. (Swarthaak, gnoibos).

Tall shrub found frequently on calcareous soils on river banks and occasionally on dunes in sandveld. On hard soils it is encouraged by overgrazing. Important food plant as leaves, flowers and pods are eaten by antelopes. Story 5566.

Acacia giraffae Willd. (Kameeldoring).

Probably the commonest tree in the Park growing in and along river courses as well as in the sandveld. In the northern parts of the Nossob riverbed it occurs in attractive park-like communities. Sandveld specimens are mostly somewhat stunted and mainly found on the crests of dunes. The pods are valuable as food especially as they are dropped in the dry season.

Not collected.

Acacia haematoxylon Hayne (Vaalkameel).

This species grows into a handsome tree in the river-beds (Avob and zone IV of Nossobl. In the sandveld it occurs as a low tree on dune tops and as a shrub in the strate between the dunes. This shrubby form is frequent in most parts of the sandveld. Leaves, flowers and pods are eaten by game. Story 5572.

Acacia hebeclada DC. var. stolonifera (Burch.) Dłr. (Trassiebos).

Dense shrub found in beds and on banks of rivers as well as in depressions in the sandveld. Prefers rather compact calcareous soils. Encouraged by overgrazing, forming thickets up to several metres in diameter. Not collected.

Acacia karroo Hayne (Soetdoring).

Only one specimen of this tree is known in the Park. It grows in the bed of the Nossob in zone III. Noted for the first time as a seedling in 1936 by the Game Warden. The seed was probably washed down from further north during the great floods in 1934. Leistner 1047.

Acacia uncinata Engl. (Swartbas, basterkameel).

Attractive tree which is occasional to frequent in the sandveld of zone I. In II it is restricted to the vicinity of the Nossob. Story 5522.

Elephantorrhiza elephantina (Burch.) Skeels (Bas, elandsboontiie).

Perennial herb with thick fleshy root. Only noticed in zones I and II. The root is said to be dug up by eland and gemsbok in search of moisture; the bark is used for tanning. Story 5552 . 
Cassia obovata Collad.

Prostrate perennial herb with attractive yellow flowers; widely distributed in sandveld. Brynard 375.

Parkinsonia africana Sond.

The only known specimen of this tree grows in the bed of the Nossob at Twee Rivieren. Not collected.

Lotononis schwanssiana Dtr. MS.

Apparently restricted to river-beds. Favoured by game. Story 5608 .

Lebeckia linearifolia E. Mey. (Bloubos).

Tall glaucous shrub with peculiar distribution: Banks and beds of rivers in zone IV and marginal zone of a single pan in zone VI. Apparently encouraged by overgrazing on sandy calcareous soil. Story 5481 .

Melolobium macrocalyx Dümm. var. longifolium Dümm.

Shrub recorded only from localities west of the Auob; rare. Story 5584.

Crotalaria sp. of C. leubnitziana Schinz

Very rare erect bush seen only in zone VI. Leistner 1038.

Crotalaria spartioides DC. (Besembos, duinebos).

Virgate shrub common in sandveld especially on dune tops. The stems remain green throughout the year but the leaves are shed in the dry season. Said to be eaten by eland. Story 5549 .

Crotalaria virgultalis Burch.

Very closely related to $C$. spartioides. It is doubtful whether Story 5549 and Brynard 413 represent two distinct species. Brynard 413.

Indigofera alternans DC.

More or less prostrate perennial growing on banks of rivers and in sandveld. Favoured by game in young state. Leistner 1006.

Indigofera auricoma E. Mey.

River banks. Brynard 405.

Indigofera diphylla Vent.

Rare prostrate perennial seen only in zone II on sandveld. I. flavicans Bak. is not regarded as a distinct species. Story 5546. 
Psoralea obtusifolia DC. (Rivierklawer).

Prostrate perennial with thick tap-root. Confined to river-beds. Food plant with high nutritive value. Story 5535.

Sylitra biflora E. Mey.

Small bush found only on calcareous soil on river banks. Leistner 1029. Tephrosia sphaerosperma DC.

Perennial with prostrate to ascending branches and thick tap-root. Frequent in sandveld. Eaten by game. Story 5547.

Lessertia macrostachye DC. var. atomaria Harv.

Virgate shrub found mainly on dune tops in area west of Auob. Story 5604. Lessertia pauciflora Harv.

Perennial confined to calcrete outcrops on river banks. Usually heavily cropped by game. Leistner 1143.

\section{GERANIACEAE}

Monsonia sp. prob. M. biflora DC.

Only one specimen of this annual was seen on a pan-like depression in zone II. Probably much more common after good rains. Leistner 1008 a.

\section{ZYGOPHYLLACEAE}

Tribulus terrestris L. (Dubbeltiies).

Widely distributed annual in beds and on banks of rivers as well as in sandveld. Encouraged by heavy grazing on hard soils. High nutritive value but poisonous when wilting. Brynard 404.

Tribulus zeyheri Sond. (Dubbeltiies).

Very similar to $T$. terrestris but flowers bigger. Apparently mainly found in sandveld. Story 5617.

Zygophyllum sp.

Bush confined to river banks. The rare specimens seen were all heavily browsed. Story 5527.

Polygala seminuda Harv.

\section{POLYGALACEAE}

Virgate shrublet seen only on calcrete outcrops along rivers. Rare, probably due to grazing. Leistner 1027. 


\section{EUPHORBIACEAE}

Phyllanthus maderaspatensis L.

Low perennial growing in and along river-beds. Brynard 221.

Jatropha erythropoda Pax et K. Hoffm.

Perennial herb with thick fleshy root. Only very rare specimens seen in sandveld of zone V. Brynard 390.

Euphorbia inaequilatera Sond.

Prostrate annual or weak perennial found mainly in sandveld. Story 5595.

\section{ANACARDIACEAE}

Rhus commiphoroides Engl. et Gilg.

Shrub growing on dune tops and on rises in zones I and II. Story 5542.

\section{TILIACEAE}

Grewia flava DC. (Rosyntiiebos).

Shrub found on banks and in beds of rivers. In the sandveld it is more or less confined to zones I and II. Only rare specimens were seen in and along the Auob. Important food plant of which leaves as well as berries are eaten. Story 5495.

Grewia retinervis Burret

Shrub more or less confined to the sandveld in zone I where it is quite common and II where it is rare. Story 5543.

\section{MALVACEAE}

Abutilon austro-africanum Hochr.

Erect one-stemmed perennial seen only in thicket on river bank in zone II. Locally frequent. Leistner 1139.

Pavonia patens (Andr.) Chiov.

Low perennial recorded only from thicket near Nossob in zone II. Leistner 1138.

Radyera urens (L.f.) Bull. (Windepampoen).

Perennial herb confined to river-beds. One of the few plants in the Park that are apparently never towched by game. Story 5521 . 
Melhania burchellii DC.

\section{STERCULIACEAE}

Rare perennial seen only in sandveld of zone II. Leistner 1007.

Hermannia abrotanoides Schrad.

Shrublet on calcareous outcrops along rivers. Leistner 1161.

Hermannia tomentosa (Turcz.) Schinz

Herbaceous perennial with tap-root and prostrate stems. Brynard 377. Hermannia sp. prob. H. grandiflora Burch. var. burchellii Harv.

Diffuse shrub confined to sandveld. Mainly found on slopes of dunes and in the strate. Leistner 1134.

Hermannia sp. cf. H. resedifolia (Burch.) R. A. Dyer

Rare perennial found on river banks. The few specimens seen were heavily browsed. Leistner 1157.

\section{THYMELAEACEAE}

Arthrosolen polycephalus C. A. Mey.

Shrub growing on river banks and in sandveld of zones I and II. Seems to prefer sandy soils overlying rock, especially limestone. Story 5562 .

\section{COMBRETACEAE}

Terminalia sericea Burch. (Geelhout).

Tree confined to deep red sand on dune tops and rises in zones I and II. Said to indicate poor grazing conditions. Apparently never touched by game. Story 5544.

\section{UMBELLIFERAE}

Pituranthos aphyllus (Cham. et Schlechid.) Benth. et Hook. f. ex Schinz

Virgate shrub abundant along a three mile stretch in the bed of the Nossob a few miles north of Twee Rivieren. Not seen anywhere else in Park. Story 5619.

Asclepias fruticosa $\mathrm{L}$.

\section{ASCLEPIADACEAE}

Occasional weedy perennial found only in river-beds. Story 5499.

Orthanthera jasminiflora N.E. Br. (Bokhorings).

Perennial with tap-root forming long prostrate annual stems. Confined to sandveld. Fruits edible. Story 5571. 
Stapelia sp. ?

Rare succulent growing on calcrete outcrops at Twee Rivieren. Story 5601. Stapelia sp. ?

Succulent on calcrete at Mata-Mata. This plant and Story 5601 could not be named as they were not in flower. They may belong to the same species. Story 5611 .

\section{CONVOLVULACEAE}

Convolvulus multifidus Thunb.

Herbaceous perennial growing on sandy river bank. Only one specimen seen. Leistner 1152.

Convolvulus ulosepalus Hall $f$.

Low perennial seen only around depressions in river-bed of Nossob. Story 5606.

Ipomoea bolusiana Schinz

Perennial with fleshy swollen root and trailing annual stems. Noticed only in sandveld. Leistner 992.

Ipomoea magnusiana Schinz

Rare perennial growing in sandveld. Leistner 1052.

\section{BORAGINACEAE}

Ehretia rigida (Thunb.) Druce

Shrub or small tree mainly found in river-beds and in the sandveld of zones I and II. As it retains some of its leaves throughout the year it has some importance as food plant, especially during the dry season. Rather rare. Story 5504.

Heliotropium curassavicum L.

Only seen in river-beds. Brynard 401.

Heliotropium lineare (E. Mey.) C. H. Wright

Perennial mainly found on compact sandy soils with a high lime content: River-beds, banks and marginal zone of pans. Brynard 397.

Heliotropium nelsonii C. H. Wright

Low perennial common in all parts of sandveld. Leistner 996.

\section{VERBENACEAE.}

Chascanum pumilum E. Mey.

Perennial found in sandveld; rare. Leistner 1000. 


\section{Acrotome angustifolia Taylor}

\section{LABIATAE}

Annual on river banks and in sandveld; sometimes locally common. Story 5555.

Stachys spathulata Burch. (Boesmantee).

Perennial herb confined to river-beds; sometimes locally abundant. Used by natives for making tea. Leistner 1016.

Lycium austrinum Miers

\section{SOLANACEAE}

Thorny shrub in rivers and on banks as well as in sandveld; occasional to rare. Leistner 1153.

Lycium echinapum Dunal.

Shrublet found in beds of rivers. Story 5488.

Lycium hirsutum Dunal

Tall shrub in river-beds, on river banks and in sandveld; occasional to rare. Leistner 1149.

Lycium tenue Willd.

Low shrub on calcareous sand. Story 5493.

Lycium sp. cf. L. hirsutum Dunal

Tall shrub very similar to $L$. hirsutum and growing alongside it in bed of Auob. They cannot be distinguished by their habit but the leaves of this form are on the whole smaller than those of $L$. hirsutum and the flowers are rarely longer than $1 \mathrm{~cm}$. while those of $L$. hirsutum are usually about $2 \mathrm{~cm}$. long. Leistner 1132.

Solanum capense L. (Bitterappel).

Perennial found in sandveld of zones I and II and on river banks. Fruit eaten by certain antelopes. Story 5568 .

\section{SCROPHULARIACEAE}

Aptosimum albomarginatum Marl. et Engl.

Low, woody perennial usually growing on calcareous sand: River banks, depressions in sandveld and marginal zone of pans. Brynard 381.

Aptosimum depressum (L.f.) Burch. var. elongatum Hiern.

Perennial with prostrate annual stems; fairly frequent in sandveld. It is doubtful whether the variety can be upheld. Brynard 385 . 
Aptosimum leucorrhizum (E. Mey.) Phill.

Perennial confined to calcrete outcrops on river banks. Brynard 383 . Aptosimum lineare Marl. et Engl.

Low, woody perennial seen on banks of rivers and in sandveld. Story 5480 .

Aptosimum marlothii (Engl.) Hiern.

Small bush found mainly in river-beds and occasionally on banks. Brynard 380.

\section{BIGNONIACEAE}

Rhigozum trichotomum Burch. (Driedoring).

Shrub commonly found on compact calcareous sand: River banks, depressions in sandveld and marginal zone of pans. The flowers which appear after the first rains in summer, the fruits and the young shoots are eaten by antelopes. Story 5505.

Catophractes alexandri D. Don. (Gabbabos).

Shrub related to Rhigozum trichotomum and growing under similar conditions. Although it is common in depressions and around pans in zone $\mathrm{I}$ it is known only from a single locality in the Kalahari Gemsbok National Park. Brynard 378.

\section{PEDALIACEAE}

Harpagophytum procumbens DC. (Kloudoring).

Perennial with thick tap-root and prostrate annual branches. Roots reported to have medicinal properties. Leistner 991.

Sesamum schenkii Aschers. (Brandboontjies).

Tall annual, occasional to frequent in sandveld. Leistner 999.

\section{ACANTHACEAE}

Barleria rigida Nees

Low woody perennial confined to hard calcareous soil on river banks. Story 5529.

Monechma hereroense (Engl.) C.B.Cl. (Perdebos).

Bush growing exclusively on limestone outcrops. Except for a few specimens next to a pan in zone II, it was seen only on river banks. Closely related to Monechma genistaefolium which has a more northerly distribution. Brynard 217. 
Monechma incanum (Nees) C.B.Cl. (Bloubos).

Bush found in depressions in sandveld and in marginal zone of pans. Reported to cause disease in antelopes. Story 5483.

Momordica balsamina L.

\section{CUCURBITACEAE}

Climber with thick perennial root. Sandveld; rare. Story 5574.

Colocynthis citrullus (L.) O.K. (Tsamma).

The fruits of the tsamma are probably the most important source of water for man and beast when no surface water is available. Not collected.

Colocynthis naudiniana (Sond.) O.K. (Gemsbokkomkommer).

Perennial with trailing annual stems. Confined to sandveld where it is occasional to rare. The fruits are edible and are sought by game. Story 5554 .

Cucumis hookeri Naud. (Wildekomkommer).

Perennial herb seen in river-beds and in sandveld. The tasty fruits are eagerly eaten by game. Leistner 1133 .

Kohautia ramosissima Bremek.

\section{RUBIACEAE}

Very rare, seen only once in the sandveld of zone VI. Leistner 998.

Pteronia mucronata DC.

\section{COMPOSITAE}

Rare bush noticed only on calcrete banks along Nossob in zone IV. Scarcity probably due to grazing. Leistner 1160.

Nolletia arenosa O. Hoffm.

Rounded bush widely ditsributed in sandveld but usually rare where found. Story 5550.

\section{Crysocoma tenuifolia Berg.}

Bush confined to calcareous sandy soil on river banks and in depressions in sandveld. Two distinct forms occur in the Park; the one is a rather compact bush with linear, almost ericoid leaves growing mainly on calcrete outcrops (Brynard 462) and the other is widely branched, has broader leaves and is mainly found in depressions in the sandveld where it may be locally abundant. This broad-leaved form is sometimes called C. polygalaefolia S. Moore. Leistner 1050.

Blumea gariepina DC.

Silvery shrub confined to the bed of the Nossob in zones II, III and IV. Story 5498. 
Gnaphalium sp.

Marginal zone of pan; rare. Story 5588.

Helichrysum argyrosphaerum DC.

Ephemeral common in sandveld after rains in April or May. Sought by game. Brynard 212.

Helichrysum dregeanum Harv. et Sond.

Perennial. Brynard 389.

Nestlera humilis Less.

Low bush on calcrete outcrops along rivers. Story 5526.

Geigeria africana Gries. (Vermeerbos).

Low perennial occurring frequently in river-beds, on banks, in sandveld and around pans. All Geigeria species are poisonous but no game losses due to them have been reported from the Park. Story 5531.

Geigeria africana Gries. ssp. ornativa (O: Hoffm.) Merxm. (Vermeerbos).

Perennial usually found on hard calcareous soils. Story 5517.

Geigeria brevifolia (DC.) Harv.

Lax bush confined to red sand. Only seen in zone II. Story 5561.

Geigeria pectidea (DC.) Harv. (Vermeerbos).

Low perennial frequent on silty sand in river-beds. Story 5479.

Eriocephalus pubescens DC.

Rare bush growing on hard calcareous soils on river banks and around pans. All specimens seen were heavily browsed by game. Story 5519.

Pentzia incana (Thunb.) O.K.

Bush seen in beds and on banks of rivers in zones III and IV. Browsed by game. Story 5528 .

Senecio arenarius Thunb.

Summer annual that can be locally common on sandy river banks and in sandveld. Reported to be poisonous. Leistner 1150.

Dimorphotheca polyptera DC.

Annual which may be common on sandy banks and in sandveld. Story 5618.

Osteospermum muricatum E. Mey.

Bush growing in and along rivers and around pans. Usually heavily browsed by game. Story 5492 . 
Berkheyopsis echinus (Less.) O. Hoffm.

Rare perennial in sandveld. Story 5563.

Berkheya ferox O. Hoffm.

Perennial recorded only from the sandveld of zone II. Story 5560.

Platycarpha carlinoides Oliv. et Hiern. (Rivierkool).

Compact perennial with flat leaves adpressed to the ground. Fairly frequent in river-beds in zones III to V. Story 5485.

Dicoma capensis Less.

Perennial found on river banks and around pans. Story 5484.

Dicoma schinzii O. Hoffm.

Prostrate perennial confined to sandveld. Brynard 392.

\section{ACKNOWLEDGEMENTS}

Thanks are due to the National Parks Board for the opportunities given to the botanists that have contributed towards the floristic exploration of the Kalahari Gemsbok National Park.

Dr. R. Story and Mr. A. M. Brynard have not only collected most of the specimens cited in this list but have also assisted with advice and suggestions.

\section{REFERENCES}

Bremekamp, C. E. B. \& Obermeyer, A. A. (1935): Scientific Results of the Vernay-Lang Kalahari Expedition, March to September, 1930. Sertum kalahariense, a list of plants collected. Ann. Trans. Mus. 16: 399-442.

Dinter, K. (1912): Die vegetabilische Veldkost Deutsch-Südwest-Afrikas. Selgstverlag, Okahandja. Koch, C. (Unpubl.): Coleoptera. Report to the National Parks Board of Trustees, May, 1956, Pretoria. Leistner, O. A. (1959): Notes on the Vegetation of the Kalahari Gemsbok National Park with special reference to its Influence on the Distribution of Antelopes. Koedoe II, 1959, p. 128.

Phillips, E. P. (1951): The Genera of South African Flowering Plants. Government Printer, Pretoria. 